\title{
Studies on High-molecular Placental Components in Connection with Pregnancy Toxemia
}

\author{
First Paper* \\ By \\ Nobuo Kanno, Kiyosi Kimura, Yosio Tanaka \\ (菅野信夫) (木村清) (田中 息雄) \\ and Yosizi Mugikura \\ (麥倉 義司) \\ From the Medico-chemical Institute (Director: Prof. H. Masamune) \\ and the Department of Obstetrics and Gynecology (Derector: Prof. \\ T. Shinoda), Tohoku University, Sendai \\ (Received for publication, October 16, 1953)
}

To elucidate the etiology of toxemia of late pregnancy, there have been put forward several theories hormone-, embryo-, hyperproteinemia-, dietetic deficiency-, placenta- and ishemia-theory, although none appears to have been firmly established.

Not a few authors ascribe the toxemia of late pregnancy to an allergic disorder, judging from the clinical symptoms as well as autopsy findings in eclampsia and premature separation of placenta. The opinion that placental substances absorbed causes it was expressed by Liepmann ${ }^{1 a}$ ) as early as 1902 and since then the placental allergen was demonstrated in the blood serum, urine and also umbilical blood of pregnant women. Regarding the placental components, Magara" ${ }^{2}$ claimed in 1942 that a polypeptide is the allergen concerned, but more recently in $1950 \mathrm{Kaku}^{3)}$ contradicted him, insisting a polysaccharide to be the allergen. The present writers have undertaken to decide whether the polypeptide or the carbohydrate or any other or others function as the allergen. With the aim extracts of placentas once dehydrated were fractioned, and a neutral carbohydrate, glacial acetic acid-soluble and acid-precipitable proteins, a mixture of nucleic acids and an itinsulfuric acid were obtained. And the products, which were not pure enough, were examined with respect to their antigenicity and other properties capable of suggesting their relationship with pregnancy toxemia (precipitin reaction with the serum of pregnancy-toxemic women, Schultz-Dale reaction, skin reaction, effects

* Read before the 5th General Meeting of the Japanese Obstetrical and Gynecological Society, May 10-12, 1953, Niigata.1) 
on pregnant rabbits after injection particularly induction of histological lesions and else).

\section{EXPERIMENTAL \\ Preliminary Fractionation of the Water-extractible Components of Placenta}

A placenta was freed from membranes and big blood-vessels and after rough washing with water, minced. The tissue pulp was covered under about 5 volumes of $95 \%$ alcohol for about 1 week and dried in a Faust apparatus. The material obtained weighing $50 \mathrm{~g}$. in averages was then refluxed with water for 1 hour. The solution was distilled in vacuo to about $1 / 10-1 / 15$ the volume and $\left(\mathrm{NH}_{4}\right)_{2} \mathrm{SO}_{4}$ was added to half saturation. The deposit (Fr. I) was set aside after centrifugation. The supernatant which contained floating particles was filtered. The filtrate was saturated with additional $\left(\mathrm{NH}_{4}\right)_{2} \mathrm{SO}_{4}$ and a small deposit was again filtered off. The filtrate here was dialyzed for about 1 week, distilled in vacuo to a syrup and precipitated with an excess of alcohol-Fr. II. On the other hand, Fr. I was subjected to the procedure of Kerr \& Seraidarian, ${ }^{4}$ namely, it was taken up in $3 \mathrm{M} \mathrm{NaCl}$ and after rejecting the insoluble part, adjusted to $\mathrm{pH} 4.2$ with dilute $\mathrm{HCl}$, then the occurring precipitate (Fr. III) was centrifuged and the supernatant precipitated with 3 volumes of alcohol. After separating the deposit (Fr. IV), the mother fluid was vacuum-distilled to about $1 / 5$ the volume to expel off most of the alcohol, dialyzed and precipitated with alcohol. The deposit here will be referred to as Fr. V.

\section{Separation of the Components}

Neutral carbohydrate (Ch.). Fr. II was dissolved in water and shaken repeatedly with a chloroform-amylalcohol $(10: 1$ by volume) mixture to eliminate proteins according to Sevag. When no more gel formed, the centrifuged upper layer was siphoned out and an excess of alcohol was added. The deposit was wahsed with alcohol and dried in a vacuum desiccator over $\mathrm{CaCl}_{2}$.

Protein I. Fr. III was taken up in the sat. $\mathrm{NaCl}$ and after rejecting the insoluble part, adjusted to $\mathrm{pH} 4.2$ with $1 \% \mathrm{HCl}$. The occurring deposit was agitated in the sat. $\mathrm{NaCl}$, adding drop by drop of $1 \% \mathrm{NaOH}$ to neutral, and the insoluble removed. Again $1 \% \mathrm{HCl}$ was added to the solution to $\mathrm{pH} 4.2$ for precipitation. Redissolution and reprecipitation was further processed again and again until a deposit showing only faint Molisch reaction was obtained. It was washed with the sat. $\mathrm{NaCl}$ acidified to $\mathrm{pH} 4.2$ with $\mathrm{HCl}$, dialyzed for 5 days against running 
water and vacuum-distilled to a thick solution, followed by standing in a vacuum desiccator over $\mathrm{CaCl}_{2}$ to complete dryness.

Protein II. Fr. V not only showed the positive biuret (\#), Molisch $(\#)$, Neuberg-Saneyoshi $(+)$ and Goldschmiedt $(+)$ reactions but also proved to contain phosphorus (H). It appeared thus to be a mixture of a neutral carbohydrate, nucleic acids, an itinsulfuric acid ${ }^{5)}$ and proteins. Hence it was at first washed well with the sat. $\left(\mathrm{NH}_{4}\right)_{2} \mathrm{SO}_{4}$ and the residue was dissolved in water, dialyzed and recovered by vacuum distillation and addition of alcohol. Then, the substance was dissolved again in water and the sat. $\mathrm{Ba}(\mathrm{OH})_{2}$ was added to $\mathrm{pH} 9.0$, whereby a precipitate occurred. After centrifuging off of the precipitate, the supernatant was acidified to $\mathrm{pH} 2.0$ with dilute $\mathrm{HCl}$, whereby again a precipitate came out which was also separated off. Moving of the $\mathrm{pH}$ hither to thither was repeated, and when the precipitable remained no more, the solution was freed from barium quantitatively by the aid of $\mathrm{H}_{2} \mathrm{SO}_{4}$, with following dialysis, condensation and alcohol-precipitation. The deposit dried was kneaded with a little water into a paste and an excess of $99 \%$ acetic acid was added in portions to carry down the neutral carbohydrate and itinsulfuric acid. The centrifuged supernatant was precipitated with more than 3 volumes of ether. The deposit here was further treated similar to above three more times, employing 90, 80 and $60 \%$ acetic acid in turn instead of the $99 \%$ acid. The final ether-deposit was dissolved in water and carried down with trichloroacetic acid $(10 \%)$. After several reprecipitations, the substance was taken up in water and dialyzed. On vacuum-distillation of the solution some precipitate was given halfway. This was rejected and the solution was further concentrated to syrupy consistency, precipitated with alcohol and dried as above.

Nucleic acids. Fr. IV which contained an abundant quantity of nucleic acids ( $\mathrm{P}$ H, Dische $\#$, Bial $H$ ) beside an itinsulfuric acid (Neuberg-Saneyoshi $H$ ) and proteins (biuret $\mathrm{H}$ ), was dissolved in water and $5 \% \mathrm{CuCl}_{2} \cdot 2 \mathrm{H}_{2} \mathrm{O}$ was added until no more precipitate occurred. Centrifuged. The supernatant-Fr. VI-was set aside for separation of the itinsulfuric acid (S. below). The centrifugate was washed with a $\mathrm{CuCl}_{2}$ solution of like concentration as the supernatant, then with $\mathrm{HCl}$ containing alcohol to remove copper and finally with alcohol. After drying, it was dissolved in water $(10 \mathrm{cc}$. per $100 \mathrm{mg}$. of the substance) and treated with a chloroform-amylalcohol mixture as above according to Sevag thoroughly. The solution was then dialyzed for 3 days and precipitated with alcohol containing sodium acetate, and the deposit was washed with plain alcohol and dried to a constant weight.

Itinsulfuric acid. The centrifuged supernatant of the cupric nucleates above (Fr. VI) was precipitated with alcohol, freed from copper with 
HCl-containing alcohol, and after washing with alcohol, dried. The substance obtained was subjected to Sevag procedure and the alcoholprecipitate of the solution which was free from proteins was dried as above in a desiccator.

Many runs of preparation were carried out, and in averages 90, $170,120,30$ and $50 \mathrm{mg}$. respectively of the neutral carbohydrate, Proteins I and II, nucleic acids and itinsulfuric acid were yielded from $50 \mathrm{~g}$. of the placental powder. The corresponding products were united.

Physical and Chemical Properties of the Products

Qualitative test-fube tests. The results are tabulated as follows:

Test

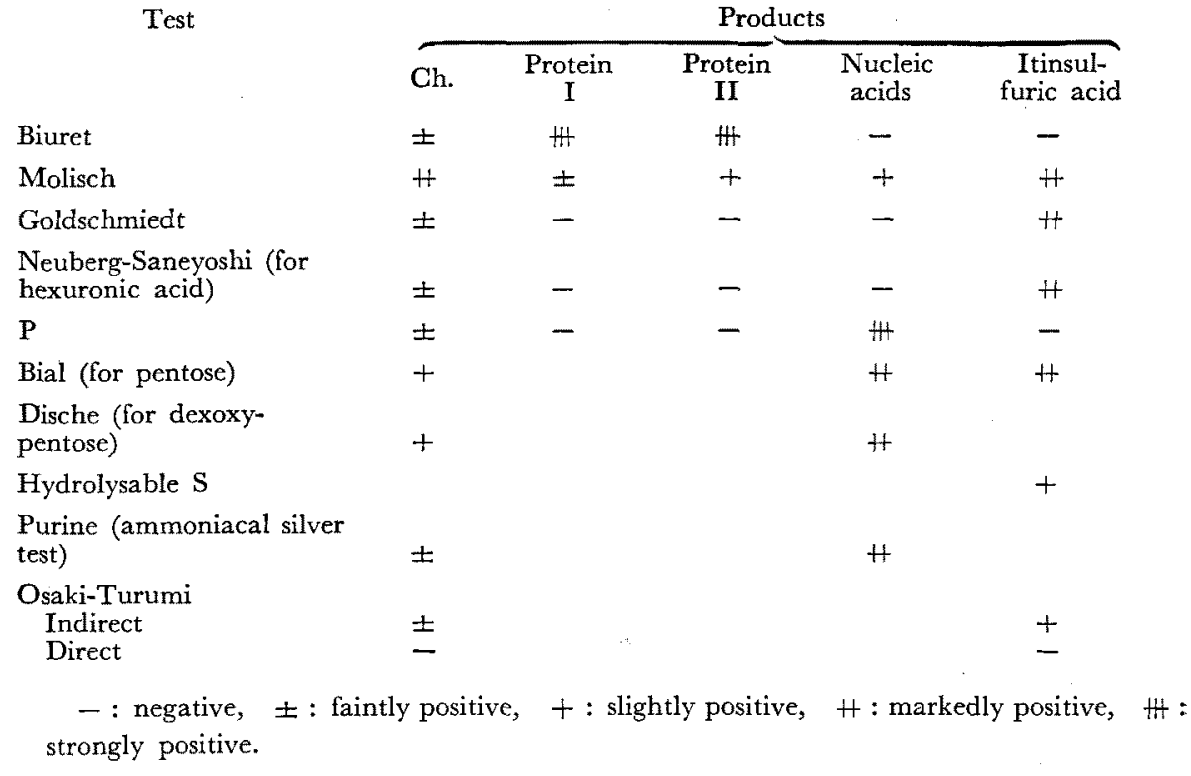

Electrophoresis. Electrophoretical examination was made in a Tiselius apparatus. The patterns given (Fig. 1) showed that Protein II was a mixture of nearly equal amounts of two proteins and the other products contained more or less of a contamination or contaminations.

Paper partition chromatography of the sugar components of the neutral carbohydrate (a polypeptide-polysaccharide complex). Masamune \& Yosizawa's procedure $^{6}$ was adapted. The carbohydrate taken for hydrolysis was $35 \mathrm{mg}$. The hydrolysate by $1 \mathrm{~N} \mathrm{H}_{2} \mathrm{SO}_{4}$ was freed from most of the mineral acid and concentrated to about $0.3 \mathrm{cc}$., and $0.035 \mathrm{cc}$. was sampled. The chromatogram given is reproduced diagrammatically in Fig. 2, which shows that the material contained chondrosamine, glucosamine, galactose, glucose, mannose and a pentose. 
Fig. 1

A

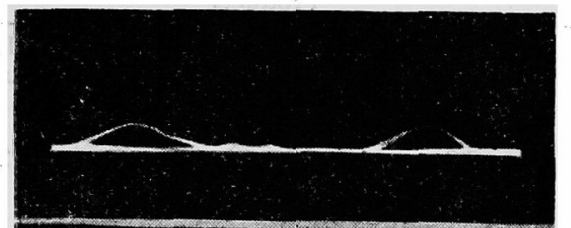

B

C

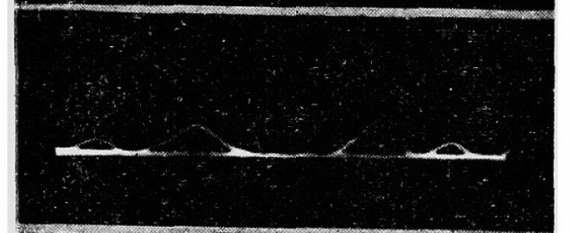

$\mathrm{D}$

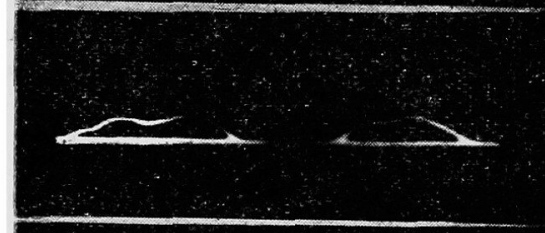

$\mathrm{E}$

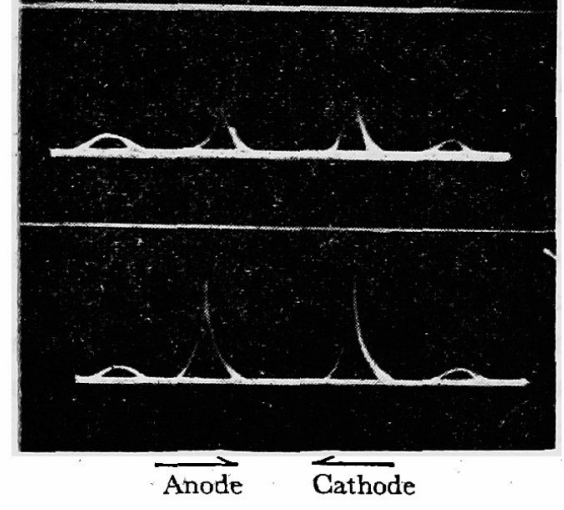

Fig. 2

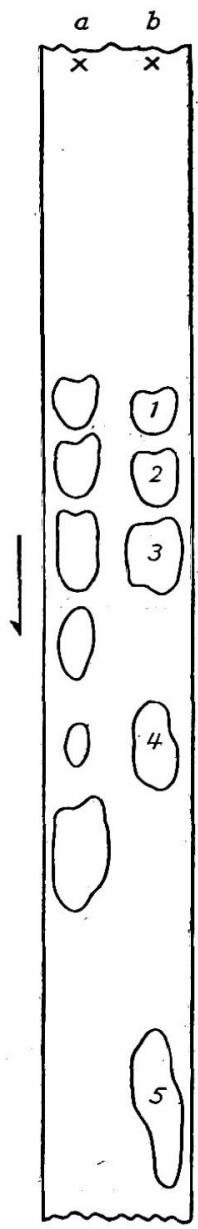

Fig. 1. Electrophoretic patterns of $1 \%$ solutions of Neutral carbohydrate (A), Protein I (B), Protein II (C), Nucleic acids (D) and Itinsulfuric acid (E) in phosphate buffer of $\mathrm{pH} 7.8$ and $\mathrm{I} 0.29$. A : temperature $19^{\circ} \mathrm{C}$; current $26.5 \mathrm{~mA}$; exposure after starting current 55 minutes. B: temp. $20.3^{\circ} \mathrm{C}$; cur. $20 \mathrm{~mA}$; expos. $50 \mathrm{~min}$. G: temp. $20.3^{\circ} \mathrm{C}$; cur. $21 \mathrm{~mA}$; expos. $50 \mathrm{~min}$. D : temp. $20.3^{\circ} \mathrm{C}$; cur. $21.8 \mathrm{~mA}$; expos. $40 \mathrm{~min} . \mathrm{E}$ : temp. $10^{\circ} \mathrm{C}$; cur. $15 \mathrm{~mA}$; expos. $35 \mathrm{~min}$. Ascending limbs to the left.

Fig. 2. A sugar chromatogram of Neutral carbohydrate obtained by descending irrigation with butanol-pyridine-water $(5: 3: 2)$ for 24 hrs. Temperature of test $25^{\circ} \mathrm{C}$. Indicator aniline hydrogen phthalate of Partridge. The standard solution was $1 \%$ with respect to individual sugars and $0.025 \mathrm{cc}$. of it was sampled.

a : main run, b: reference run, 1: chondrosamine hydrochloride, 2 : glucosamine hydrocholoride, 3 : galactose, 4 : mannose, 5 : rhamnose. 
Quantitative analysis. The figures (percentages) below were obtained.

\begin{tabular}{|c|c|c|c|c|c|}
\hline \multirow[t]{2}{*}{ Analysis } & \multicolumn{5}{|c|}{ Products } \\
\hline & Ch. & $\begin{array}{l}\text { Protein } \\
\text { I }\end{array}$ & $\begin{array}{c}\text { Protein } \\
\text { II }\end{array}$ & $\begin{array}{c}\text { Nucleic } \\
\text { acids }\end{array}$ & $\begin{array}{l}\text { Itinsul- } \\
\text { furic acid }\end{array}$ \\
\hline $\mathrm{N}^{*}$ & 4.3 & 12.9 & 14.6 & 12.0 & 3.1 \\
\hline Hexosamine† & 14.9 & 2.9 & 5.9 & & 24.8 \\
\hline $\mathbf{P} \ddagger$ & & & & 4.9 & \\
\hline Galactose§ & 30.4 & & & & \\
\hline Glucose $\$$ & 9.3 & & & & \\
\hline Mannose§ & 6.0 & & & & \\
\hline Pentose as xylose// & 13.1 & & & & \\
\hline Ash & $3.0 \pi$ & 2.01 & $7.2 \uparrow$ & $19.2 *$ & $9.2 \pi$ \\
\hline
\end{tabular}

* Micro Kjeldahl, † Hamasato \& Akakura, † Haneda, Sinokawa \& Yasuoka's modification of Plimmer method, \& Masamune \& Ogawa7), // Masamune \& Ogawa ${ }^{8), ~ I ~ P r e g l ~}$ method without use of $\mathrm{H}_{2} \mathrm{SO}_{4}$, ** Pregl.

\section{Biological Assays}

1) Precipitin reaction of the products with the sera of non-pregnant, normal-pregnant and pregnancy-toxemic women. $2 \%$ solutions of the products in physiological saline were diluted progressively with the saline solution and after laying over the sera above, stood in air for 4 hours. The results are illustrated in Table I. The products gave the positive reaction with some of the sera of pregnancy-toxemic women, but three of them (Ch., Nucleic acids and Itinsulfuric acid) reacted also with some of the sera of normal-pregnant women though less in number. It is noteworthy that the reaction with the sera of seriously pregnancy-toxemic women was not always positive.

2) Schultz-Dale reaction. $3 \mathrm{cc}$. of the serum of a pregnancytoxemic woman were injected intraperitoneally to a guinea pig of 200$300 \mathrm{~g}$. body weight. After 24-48 hours from the injection, the animal was killed by bloodletting and a part of the intestine was cut out and hung in $10 \mathrm{cc}$. of Tyrode solution of $37-38^{\circ} \mathrm{C}$ which was being bubbled with oxygen (Magnus apparatus). And, when the intestine showed constant peristalsis, 5-10 mg. of one of the products, dissolved in $1 \mathrm{cc}$. of Tyrode solution, were added to the bath to see if it causes any contraction of the tissue. The others were assayed also on the same tissue in a similar manner, renewing each time the fluid in which the tissue was suspended. None of the products gave a positive result.

3) Pathological changes in liver and kidney of pregnant rabbits after intravenous injection of the products. 5 or $10 \mathrm{mg}$. per $\mathrm{kg}$. body weight of each of the products were dissolved in physiological saline and 
TABLE IA

Precipitin Reaction with the Sera of Non-pregnant, Normalpregnant and Pregnancy-toxemic Women of the Neutral

Carbohydrate

- : no reaction, \pm : faintly positive $r .,+$ : slightly positive $r$.

\begin{tabular}{|c|c|c|c|c|c|c|c|}
\hline \multirow{2}{*}{$\begin{array}{l}\text { No. of } \\
\text { individuals }\end{array}$} & \multicolumn{4}{|c|}{ Dilution of products (1: ) } & \multicolumn{3}{|c|}{ Symptoms of patients } \\
\hline & $\begin{array}{l}5 \times \\
10\end{array}$ & $10^{2}$ & $\begin{array}{l}1.5 \\
\times 10^{2}\end{array}$ & $\begin{array}{l}2 \times \\
10^{2}\end{array}$ & $\begin{array}{l}\text { Blood pressure } \\
(\mathrm{mm} . \mathrm{Hg})\end{array}$ & $\begin{array}{c}\text { Albumi- } \\
\text { nuria }\end{array}$ & Edema \\
\hline \multicolumn{8}{|c|}{ Sera of non-pregnant women } \\
\hline 1 & - & - & - & - & & & \\
\hline 2 & - & - & - & - & & & \\
\hline 3 & - & - & - & - & & & \\
\hline 4 & \pm & - & - & - & & & \\
\hline 5 & - & - & - & - & & & \\
\hline
\end{tabular}

Sera of normal-pregnant women

\begin{tabular}{r|llll|}
\hline 6 & + & - & - & - \\
7 & \pm & - & - & - \\
8 & - & - & - & - \\
9 & - & - & - & - \\
10 & - & - & - & - \\
\hline
\end{tabular}

\begin{tabular}{l|cccc|cccc}
\hline \multicolumn{7}{|c}{ Sera of pregnancy-toxemic women } \\
\hline 11 & + & \pm & \pm & - & $160-110$ & $(+)$ & $(+)$ \\
12 & - & - & - & - & $200-140$ & $(+H)$ & $(H)$ \\
13 & \pm & - & - & - & $182-130$ & $(+H)$ & $(+)$ \\
14 & \pm & - & - & - & $155-95$ & $($ H) & $(+)$ \\
15 & - & - & - & - & $150-88$ & $(-)$ & $(+)$ \\
16 & - & - & - & - & $135-70$ & $(+\#)$ & $(+)$ \\
17 & - & - & - & - & $162-100$ & $(+)$ & $(-)$ \\
18 & + & \pm & - & - & $220-145$ & $(+H)$ & $(+)$ \\
19 & + & \pm & - & - & $165-110$ & $(+)$ & $(+)$
\end{tabular}

injected into the auricular or portal vein of a rabbit of late pregnancy and after 24 or 48 hours, the animal was killed. The tissues were fixed with formalin or with alcohol and stained by hematoxylin-eosin, van Gieson, Weigert (for fat staining) and Kawamura-Yazaki (for fibril staining) methods. The control was carried out on non-pregnant female rabbits, in whose tissues almost no changes occurred. The histological findings in the main experiment are embodied in Table II. In liver, necrosis occurred by any of the products. The change was caused comparatively easily by the nucleic acid and itinsulfuric acid fractions. And, 


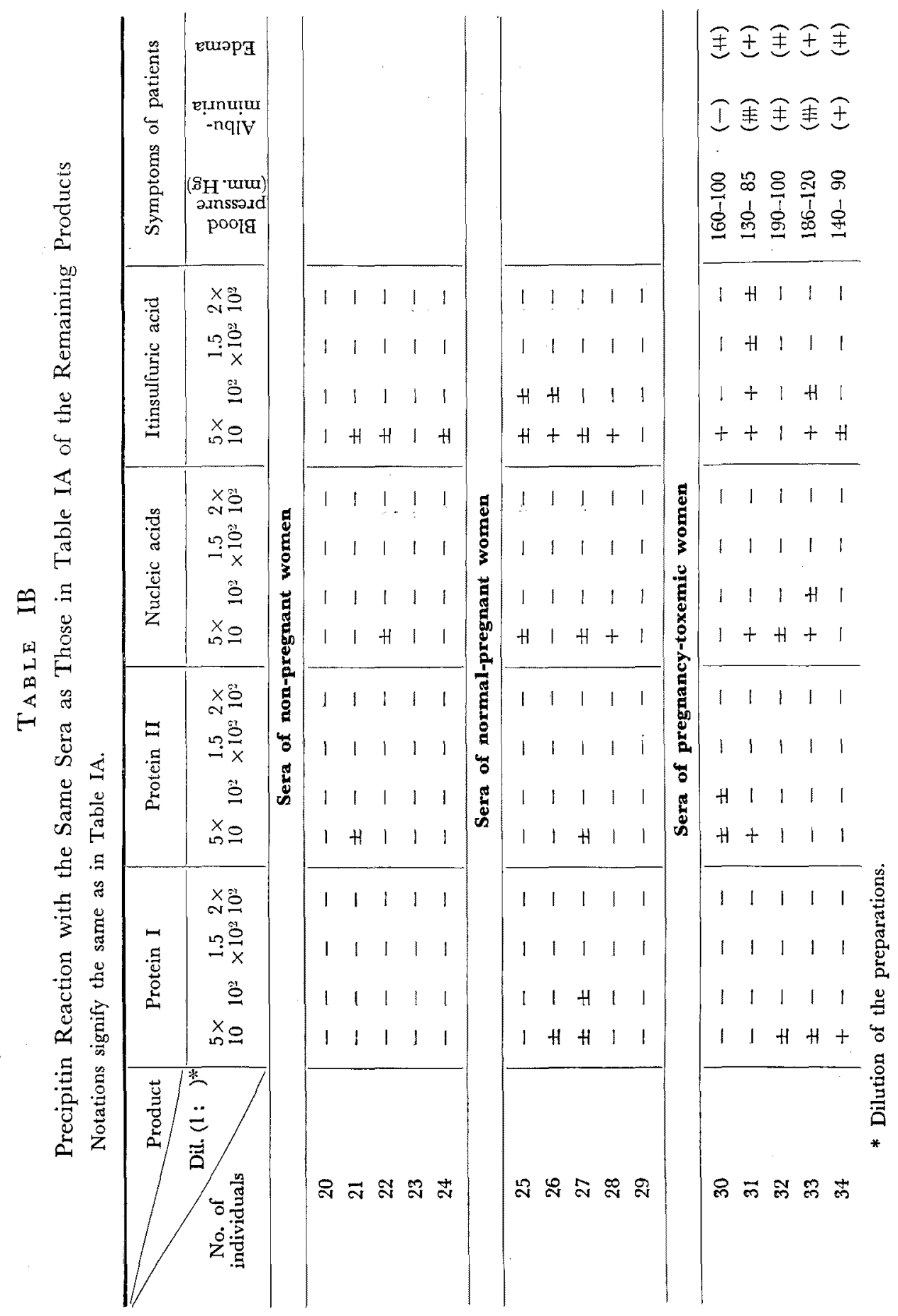


High-molecular Placental Components and Pregnancy Toxemia-I

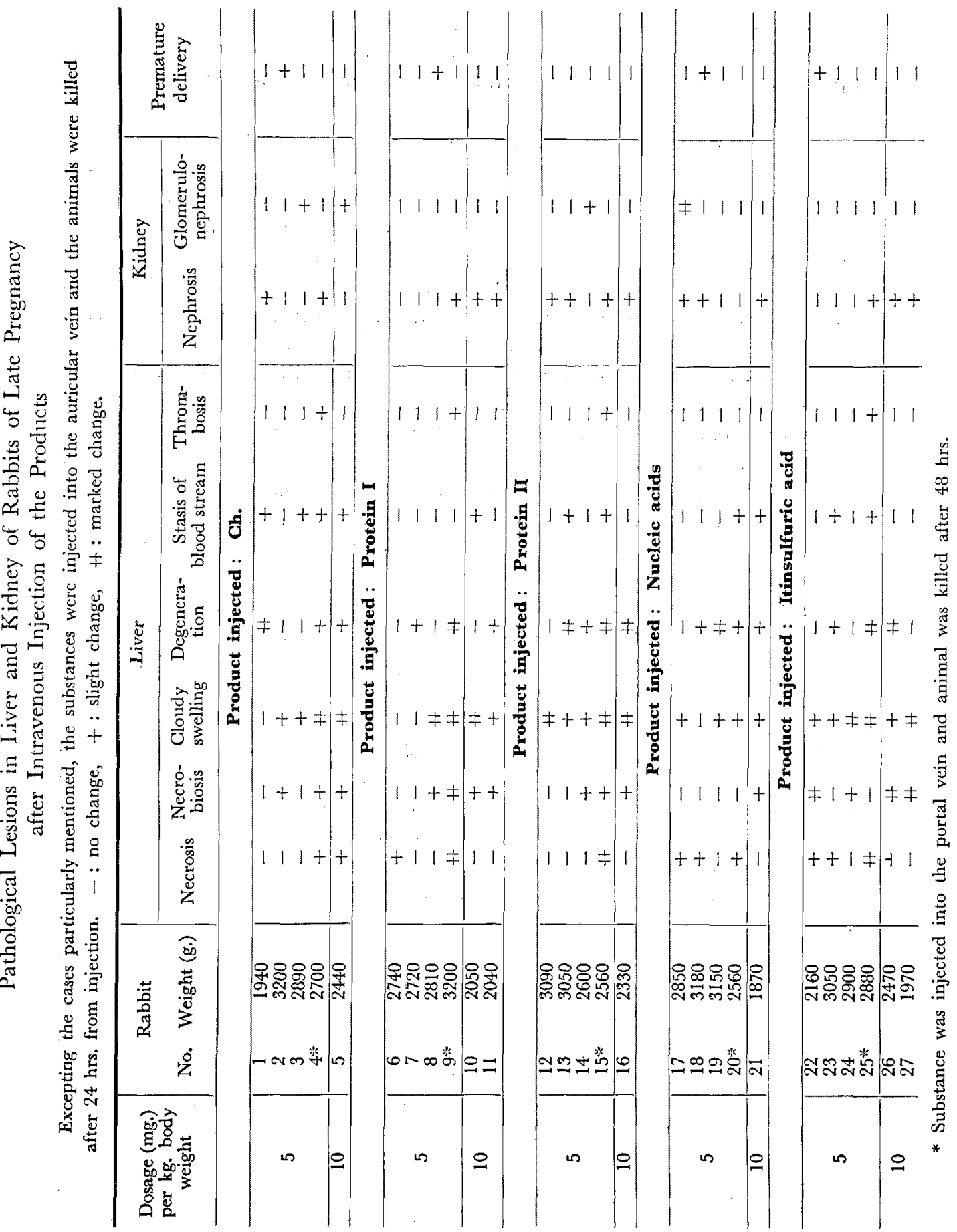


in kidney, nephrosis or glomerulonephrosis was induced also by all the products, of which Nucleic acids, Neutral carbohydrate and Protein II appeared to be more poisonous than the others. However, none of the products gave rise to the characteristic allergic changes of Rössle.

4) Schwartzman reaction. B. coli com. was cultured in an agar medium for 24 hours. Then it was inoculated in bouillon of $\mathrm{pH} \mathrm{7.3-}$ 7.4 (2 platinum loops for $10 \mathrm{cc}$.) and stood in an incubator at $37^{\circ} \mathrm{C}$ for 5 days, followed by straining through a Seitz filter. The filtrate was kept sterile in a refrigerator and used within 10 days. a) Examination of the preparatory potency of the products for Schwartzman reaction. $0.3 \mathrm{cc}$. portions of the B. coli com. filtrate were intracutaneously injected at symmetric two points in the epigastric region of a rabbit and $0.3 \mathrm{cc}$. portions of a $0.1 \%$ solution of one of the products in physiological saline at two symmetric points in the hypogastric region and after 24 hours, 1 cc. of the bacterial filtrate per $\mathrm{kg}$. body weight was injected into the auricular vein. The result was judged after 5 hours (Table IIIA). Proteins I and II and Nucleic acids were seen to have skin-preparatory potency for the bacterial filtrate intravenously injected.

b) Examination of the reacting potency of the products in the phenomenon. The preparatory injection was processed as above and the reacting injection by replacing $1 \%$ solutions in physiological saline of the products for the bacterial filtrate. As is illustrated in Table IIIB, the areas preparatorily injected showed the positive reaction after reacting injection of Proteins I and II.

5) Skin reaction. The products were separately dissolved in 1500 volumes of physiological saline containing $0.5 \%$ phenol. $0.1 \mathrm{cc}$. portions of the solutions were injected intracutaneously to non-pregnant, normalpregnant and pregnancy-toxemic women, and the longest and shortest diameters of the reddened injected-areas were measured after 4 hours. No noticeable discrepancy of the area was shown by any of the products among the different groups of women. A study with $0.05 \%$ solutions will be described in detail in a forthcoming paper.9)

6) Effect of the products on blood pressure of pregnant rabbits. If a female rabbit is sensitized during pregnancy by placental specific components, her blood pressure might be lowered by injection of at least some of the products as an anaphylactic reaction. Therefore, an urethanenarcotized pregnant rabbit was fettered on her back and the intravascular pressure in the carotic artery was recorded on a kymograph, injecting $3 \mathrm{cc}$. of a solution in physiological saline containing $5 \mathrm{mg}$. per $\mathrm{kg}$. body weight of one of the products into the auricular vein. But, contrary to expectation, no depression took place by any of the products (Table IV).

7) Spasm in the arterioles of retina, albuminuria and premat. 


\section{TAB LE IIIA}

Skin-preparatory Potency of the Products for Schwartzman Reaction

- : no change, \pm : faint hemorrhage, $t$ : slight hemor. or a petechia, $\#$ : marked hemor. with or without necrosis of the center of swelling, $\#$ : intense infiltration and swelling of the injected area with dark red necrosis and hemor.

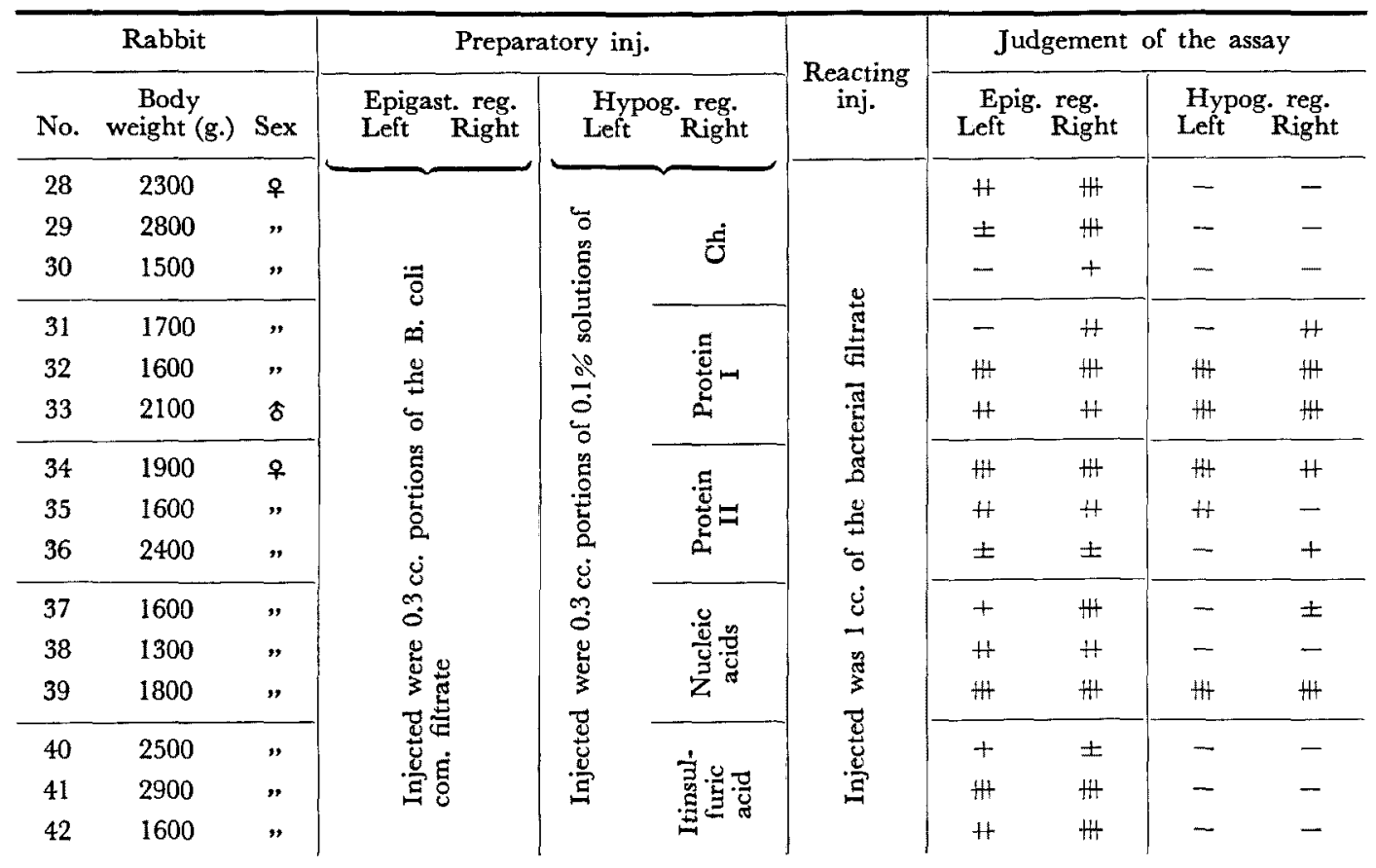

ure delivery of the pregnant rabbits injected with the products. In pregnancy toxemia particularly eclampsia and pre-eclampsia there is seen the spasm in the central artery of retina. Hence, into the auricular vein of pregnant rabbits were injected a 5 or $10 \mathrm{mg}$. portion per $\mathrm{kg}$. body weight of the placental products after dissolution in $5 \mathrm{cc}$. of physiological saline, to observe the blood vessel of retina by direct ophthalmoscopy after 30 minutes and after 24 hours from the injection. None of the products caused the spasm, whereas premature delivery occurred by all of them exclusive of Protein II as shown in Table II. Albuminuria did not happen.

\section{SUMmary}

1. High-molecular substances (a neutral carbohydrate, a protein precipitable at $\mathrm{pH} 4.2$ (Protein I), a mixture of proteins soluble in glacial acetic acid (Protein II), a mixture of nucleic acids (PNA and DNA) and 
TABLE IIIB

Reacting Potency of the Products for Schwartzman Reaction Notations signify the same as in Table IIIA.

\begin{tabular}{|c|c|c|c|c|c|c|c|c|c|c|}
\hline \multicolumn{3}{|c|}{ Rabbit } & \multicolumn{3}{|c|}{ Preparatory inj. } & \multirow{2}{*}{$\begin{array}{l}\text { Reacting inj. } \\
\text { (Product and } \\
\text { amount inj.) }\end{array}$} & \multicolumn{4}{|c|}{ Judgement of the assay } \\
\hline No. & $\begin{array}{c}\text { Body } \\
\text { weight (g.) }\end{array}$ & Sex & $\begin{array}{l}\text { Epigast. reg. } \\
\text { Left Right }\end{array}$ & $\begin{array}{c}\mathrm{Hy} \\
\text { Left }\end{array}$ & $\begin{array}{l}\text { og: reg. } \\
\text { Right }\end{array}$ & & $\underset{\text { Left }}{\mathrm{Ep}_{\mathrm{p}}}$ & $\begin{array}{l}\text { eg. } \\
\text { light }\end{array}$ & $\begin{array}{l}\mathrm{Hy} \\
\text { Left }\end{array}$ & $\begin{array}{l}\text { reg. } \\
\text { ight }\end{array}$ \\
\hline 43 & 1600 & 우 & $\stackrel{\infty}{\varrho}$ & $\stackrel{g}{g}$ & Ch. & $16 \mathrm{mg} . \mathrm{Ch}$. & - & - & - & - \\
\hline 44 & 1600 & $"$ & 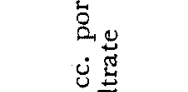 & $\begin{array}{l}\text { 范 } \\
\dot{0} \\
\dot{0}\end{array}$ & Prot. I & $\begin{array}{l}24 \mathrm{mg} . \text { Prot. } \\
\mathrm{I}\end{array}$ & $H$ & H & $\div$ & + \\
\hline 45 & 1560 & $\delta$ & 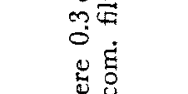 & $\stackrel{\infty}{:}$ & Prot. II & $\begin{array}{l}24 \mathrm{mg} . \text { Prot. } \\
\text { II }\end{array}$ & \pm & H & \pm & - \\
\hline 46 & 1600 & 우 & 3 & $\begin{array}{l}30 \\
350 \\
0\end{array}$ & $\begin{array}{l}\text { Nucleic } \\
\text { adids }\end{array}$ & $\begin{array}{l}16 \mathrm{mg} . \text { Nuc- } \\
\text { leic acids }\end{array}$ & - & - & - & - \\
\hline 47 & 1800 & 今 & 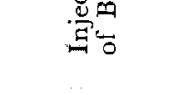 & 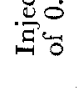 & $\begin{array}{l}\text { Itinsulfu- } \\
\text { ric acid }\end{array}$ & $\begin{array}{l}24 \mathrm{mg} \text {. Itin- } \\
\text { sulfuric acid }\end{array}$ & - & - & $\rightarrow$ & - \\
\hline
\end{tabular}

\section{TABLE IV}

Behaviour of Blood Pressure in Carotic Artery of Pregnant Rabbits, when the Products were injected into Auricular Vein

\begin{tabular}{|c|c|c|c|c|c|c|c|}
\hline \multirow{3}{*}{ Product injected } & \multirow{3}{*}{\multicolumn{2}{|c|}{$\begin{array}{cc} & \text { Rabbit } \\
\text { No. } & \text { Weight }\end{array}$}} & \multicolumn{5}{|c|}{ Blood pressure (mm. $\mathrm{Hg}$ ) } \\
\hline & & & \multirow{2}{*}{$\begin{array}{l}\text { Before } \\
\text { inj. }\end{array}$} & \multicolumn{4}{|c|}{ Time after inj. (min.) } \\
\hline & & & & $1 / 2$ & 1 & 2 & 3 \\
\hline Ch. & 48 & 1900 & 82.8 & 89.5 & 88 & 84 & 85 \\
\hline Protein I & 49 & 2300 & 84 & 85 & 85 & 83 & 85 \\
\hline Protein II & 50 & 2500 & 102 & 110 & 111 & 107 & 110 \\
\hline Nucleic acids & 51 & 1700 & 93 & 98 & 98 & 99 & 103 \\
\hline Itinsulfuric acid & 52 & 1800 & 81 & 83.5 & 85 & 85 & 88.5 \\
\hline
\end{tabular}

an itinsulfuric acid) were separated from placentas. Examined physically and chemically, the preparations proved to be mostly contaminated more or less.

2. Schultz-Dale assay did not afford a proof of the presence in the sera of pregnancy-toxemic women of antibodies of those components.

3. Precipitin test suggested the presence of antibodies of the products in some of the sera of normal-pregnant women and more of the sera of the pregnancy-toxemic.

4. The products gave rise to no spasm in the retinal arterioles nor change of intravascular pressure of the carotic artery nor albuminuria 
in pregnant rabbits, but all of them excepting Protein II caused premature delivery.

5. Pregnant rabbits underwent pathological lesions of liver and kidney resembling those in pregnancy toxemia by intravenous injection of the preparations, the degree of change depending on the preparation, although Rössle's characteristic allergic changes were not found in those tissues.

6. Proteins I and II proved Schwartzman-active.

\section{CONGLUSION}

The placental components are considered to be causative of pregnancy toxemia partially at least, although it is difficult to decide which are the most effective among them from the present experimental facts.

Through the Grant Committee for Scientific Researches was given a grant from the Education Department to carry out this work, which is gratefully acknowledged. H. Masamune and T. Shinoda.

\section{References}

1) Kanno, Suzuki, Kimura, Tanaka \& Uno, Nippon Sanka-Fujinka Gakkai Zasshi (J. Jap. Obst. \& Gynecol.), 1953, 5, No. 3, 50.

1a) Liepmann, Deut. med. Wschr., 1902, 28, 911.

2) Magara, Nihon Igaku (Jap.), 1942, No. 3274, 577 ; Taiwan Igaku (Jap.), 1943, 42, 1085 ; ibid., 1944, 43, 264.

3) Kaku, Sogo Igaku (Jap.), 1950, 7, 116 ; ibid., 1950, 7, 460.

4) Kerr \& Seraidarian, J. Biol. Chem., 1949, 180, 1203.

5) Cf. Masamune \& Ogawa, Tohoku J. Exp. Med., 1952, 56, 269.

6) Masamune \& Yosizawa, ibid., 1953, 59, 1.

7) Masamune \& Ogawa, ibid., this volume, p. 11.

8) Masamune \& Ogawa, ibid., this volume, p. 23.

9) Masamune \& Kanno, ibid., in press. 